\title{
Exploring interest intermediation in Central and Eastern Europe: is higher education different?
}

\author{
Michael Dobbins ${ }^{1} \cdot$ Brigitte Horváthová ${ }^{1}$ Rafael Pablo Labanino
}

Accepted: 3 September 2021 / Published online: 22 October 2021

(c) The Author(s) 2021

\begin{abstract}
Higher education interest groups remain somewhat understudied from a comparative theory-driven perspective. This is surprising because political decisions regarding higher education must increasingly be legitimized to students, taxpayers, the academic community and society. This article aims to advance our understanding of higher education stakeholders in post-communist Europe. In our view, the region deserves more attention, not least because students and academics were very instrumental in bringing down communism and institutionalizing democracy. First, we draw on Klemenčič's (EJHE 2(1): 2-19, 2012; SHE 39(3):396-411, 2014) distinction between corporatist and pluralist as well as formalized and informal systems of representation in higher education. Looking at survey data from four countriesPoland, the Czech Republic, Hungary and Slovenia-we examine to what extent post-communist democracies have established corporatist institutions to facilitate the formal participation of various crucial stakeholder organizations, e.g. students' unions, academic unions, rectors' conferences, etc. Then we address whether higher education organizations enjoy privileged access to policy-makers compared to those from other policy areas, while engaging with the argument that higher education is a particular case of "stakeholder democracy" in a region otherwise characterized by weak civic participation and corporatism. To wrap up, we discuss different "mutations of higher education corporatism" in each country.
\end{abstract}

Keywords Higher education · Organized interests · Central and Eastern Europe · Student unions · Rectors' organizations

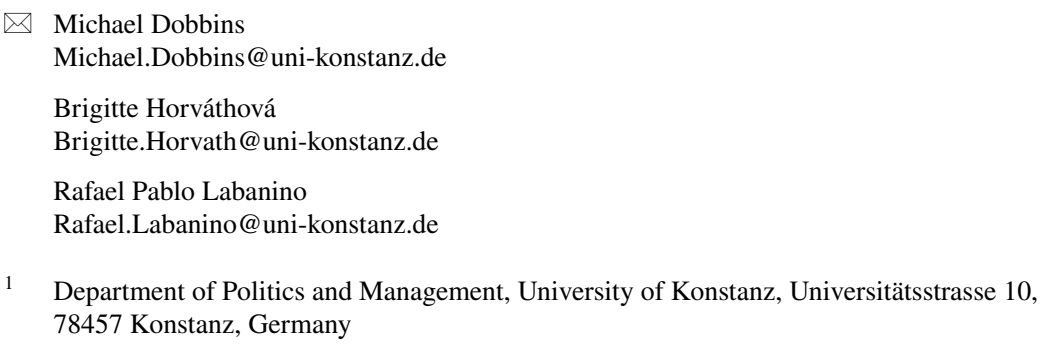




\section{Introduction}

Higher education (HE) interest groups remain understudied despite recent heavy reform activity. This is surprising because HE weighs heavily on public and private budgets and HE-related decisions must increasingly be legitimized towards stakeholders. These include not only (fee-paying) students and the academic community, but also taxpayers and society in general in the knowledge-oriented twenty-first century (Vukasović 2018). This article advances our understanding of HE stakeholders in Central and Eastern Europe (CEE). We believe the region deserves more attention, not least because students and academics were very instrumental in bringing down communism and institutionalizing democracy. Despite large-scale crackdowns on academic freedom, academic and student organizations repeatedly managed to adapt and outfox communist regimes.

The reestablishment of academic self-governance and freedom were key aspects of the (re-) democratization of CEE. This led to novel arrangements for stakeholder governance to protect the integrity of the academic community and ensure students' rights (Dobbins 2011b). Post-communist HE systems also experienced exponential growth in both student numbers and new public and private institutions. CEE universities were not only key drivers of political change, but also served to channel human capital into rapidly growing market economies. However, the democratization process, broadly speaking, has been characterized by "ups" and "downs". Hungary and Poland, in particular, have experienced both phases of rapid consolidation of liberal democracy, but also trends towards democratic backsliding (Sata and Karolewski 2020). In either case, academic communities and students have been highly present actors, and not necessarily in the more liberal camp.

This analysis provides comparative insights into interest intermediation structures in post-communist HE. Instead of focusing on specific policy-making processes, we are interested in how organized interests interact with the state. How do they bring their interests to bear and do certain groups enjoy privileged access to decision-makers? These questions are all the more important amid the Europeanization and internationalization of the policy area. Most notably, the Bologna Process offered HE stakeholders-students, academics, university lobbyistsnew opportunities to internationally engage with like-minded actors. Since the 2001 Bologna Conference held in Prague, national governments have been given new incentives to include students and other external stakeholders into governance processes (Jungblut and Weber 2012).

Against this background, we comparatively examine the position of HE organized interests in Poland, the Czech Republic, Hungary and Slovenia. Drawing on Klemenčič's $(2012,2014)$ distinctions between corporatist and pluralist HE stakeholder regimes as well as formalized associations of academic interest groups and academic social movements, we explore how post-communist democracies have enabled stakeholder participation by student unions, professional academic organizations, rectors' conferences and university workers' associations. We explore survey data covering a vast majority of national-level HE advocacy 
groups from the four mentioned countries and nearly all "encompassing organizations", i.e. major HE organizations with an umbrella-like character representing universities, academics, students or university workers as a whole (Olson 1982).

After a historical overview, we explore patterns of coordination between academic organizations and the state. This enables us to assess whether various key stakeholder groups (e.g. students', university workers' associations) have equal or distorted access to HE-related consultations. Based on our larger survey-based dataset also comprising healthcare and energy organizations, we then assess whether HE organizations differ from other organizations regarding access to political institutions. Thus, we address whether HE governance represents a special case of "stakeholder democracy" in a region otherwise characterized by weak civil society (Howard 2003; Guasti 2016) and lacking corporatist structures (Jahn 2016).

\section{HE stakeholders in CEE and beyond}

Considering the increasing number of individuals active in HE, interest organizations have become increasingly relevant actors. Altbach (1997), for example, provided an outstanding historical account of student activism in the USA. LuescherMamashela (2013) discusses changes in student governance resulting from the "democratization" of western universities in the 1960s and the recent trend towards managerialism, while also putting forward arguments against student representation. McLendon et al. (2009) extend the focus beyond student engagement and incorporate other stakeholders such as university lobbyists into their analysis of the impact of interest groups on American HE funding.

Drawing on Schmitter and Streeck's (1999) logic of influence and logic of membership, Klemenčič $(2012,2014)$ has written extensively on student organizations in Europe. She and others (e.g. Jungblut and Weber 2012) show how national student organizations engage in a two-level game: they simultaneously interact with their members to absorb their interests and ensure their support, while interacting with political authorities and specific university decision-making bodies (Klemenčič 2012). She also distinguishes between formalized student associations as interest groups and social movements promoting student causes. While the former generally demonstrate hierarchical structures, stable funding arrangements and more professionalized internal organizational regimes, the latter are mainly looser civic movements heavily reliant on volunteers (see della Porta and Guzmán-Concha 2020). Klemenčič (2012) also classifies various HE systems as corporatist or pluralist. In the corporatist paradigm (see Siaroff 1999; Jahn 2016), the state engages with a few intermediary associations of an encompassing character, often resulting in representation monopolies. This may go hand in hand with set funding arrangements for selected organizations in exchange for a steady flow of information and expertise. Pluralist arrangements, by contrast, are characterized by unstable groups and alliances of both genuine interest groups and academic movements, often competing for access to decision-makers and with one another. Membership is generally voluntary and the state negotiates ad hoc with some groups. Other more state-centred arrangements may also exist in which a strong, technocratically operating executive 
dominates policy-making without regularly consulting non-governmental stakeholders (Woll 2009). Building on Klemenčič's analyses (2012, 2014), Vukasović (2018) also includes non-student organizations representing HE academic staff and institutions and/or management. Staff organizations are essentially trade unions with high autonomy and a strong professional ethos (2018, 420). Organizations representing HE institutions generally comprise rectors' conferences and alliances of university groups (e.g. polytechnics, research-oriented universities, private universities, etc.).

Against this background, numerous questions emerge regarding HE stakeholders in $\mathrm{CEE}$ and beyond. How do they interact with policy-makers? Are they insiders or outsiders in policy-making? Are more concentrated interests (e.g. rectors) given biased representation to the detriment of more diffuse groups (e.g. students)? Is student representation formalized, or more akin to social movement activism? Do corporatist constellations facilitate consensus with selected organizations? And has the idea of a HE "stakeholder democracy", which emerged after the collapse of communism and was heavily promoted during the Bologna Process, been consolidated over time?

\section{The historical context}

While authors have begun to address these questions for various western countries (see Jungblut and Weber 2012 for Germany, Dobbins 2014 for France, Weimer 2015 for Finland), we still have little comparative knowledge on academic stakeholder organizations in CEE. This is surprising considering its moving history of academic activism, which we now briefly elaborate on.

\section{Poland}

Polish academic history is uniquely turbulent. While Poland hosts some of Europe's oldest universities (e.g. Kraków), the partitions of Poland resulted in the territorial fragmentation of Polish academia. Poland's reconstitution after World War I heralded a phase of expansion based on Humboldian academic self-governance (Scott 2002), only to be terminated by the Nazis, who murdered scores of Polish academics. The hardships continued when the Soviet Army executed much of the remaining Polish intelligentsia in Katyń in 1940.

Student self-governance dates back to the nineteenth century, when students created systems of mutual cooperation (bratniaki) for non-ideological interest representation (Junes 2015). After World War II, the Federacja Polskich Organizacji Studenckich unified the bratniaki under one umbrella organization, only to be disbanded by the communists and replaced by the Zrzeszenie Studentów Polskich (Polish Students' Association) in 1950. However, it maintained ideological pluralism (Junes 2015, 81), enabling students to become heavily involved in the 1956 Poznan workers' revolt.

In the 1970s, all existing student organizations were "Sovietized" with the Socjalistyczny Zwiazek Studentów Polskich (Socialist Union of Polish Students). Yet dissatisfaction with its ideological proximity to the regime led to the creation of 
various splinter organizations and then in the late 1970s to student sections of the Solidarity movement. Emulating workers' demands for self-managing trade union structures, oppositional students created the Niezależne Zrzeszenie Studentów (Independent Students' Association-NZS), while groups at individual HE institutions established their own self-government councils (Junes 2015).

However, the communist regime disbanded the NZS and renamed the Socialist Union of Polish Students back to Polish Student's Association (Zrzeszenie Studentów Polskich-ZSP), which had existed before 1973. During communism's gradual demise, the NZS reemerged, only to be banned again under martial law. After 1989, the trauma of occupation was a major leitmotiv of Polish academics' struggle to preserve institutional autonomy (van Beek 1995). The $1990 \mathrm{HE}$ Act decentralized power to university self-government bodies. Academic senates were modelled according to parliaments, whereby leading academics accounted for approx. $90 \%$ of representation. Academics also rapidly mobilized to collectively assert themselves at the state level by establishing the General Council for Science and Higher Education (Rada Glówna Nauki i Szkolnictwa Wyższego) (OECD 2006, 77) and Polish Rectors' Conference (KRASP, founded 1997) to politically advocate narrower interests of university managers.

NZS was relegalized in 1989, but later limited its political activities. The ZPS, by contrast, lost significance and ceased to exist at many HE institutions. However, post-communist Poland experienced a boom in new students' organizations (see Dobbins et al. 2021), most notably the Parlament studentów founded in 1995 as a self-managing, but state-financed formal representation body of all Polish students, and the national-conservative, more grassroots-based Studenci dla rzeczpospolity in 2010 .

\section{Czech Republic}

Czech HE also exhibited a long self-regulatory tradition before succumbing to communism. Even before the Prague Spring in 1968, the Czechoslovak Youth Movement (Československý svaz mládeže) openly criticized Stalinism and called for economic reforms (Šustrová 2007). Student, academic and civic groups mobilized with trade unions against Soviet control and vociferously advocated for democracy, only to have their hopes crushed by the 1968 Soviet invasion (Kavan 2018). In 1969, the student Jan Palach burned himself to death in protest-a symbolic tragedy uniting Czech academics, students and civil society.

In the late 1970s, anti-communists, workers, students, intellectuals coalescing around the idea of human rights, tolerance and free speech signed the Charter 77. However, it was confiscated and the loose civic initiative was forced to operate underground (Kraus 2007). The anti-communist movement again gathered around the Palach tragedy 20 years later, bringing thousands of students and dissidents to the streets of Prague in 1989 for the so-called "Palach Week" (Kopsa 2019). Students plastered the Charter 77 on the city's walls and indisputably became crucial collective actors driving the Velvet Revolution and democratization, not only through their key presence in oppositional circles, but also by disseminating democracy-promoting literature and information material (Otáhal 2003; Nantl 2018). 
Driven by student and academic demands for liberty, Humboldtian self-governing, "democratized" universities were quickly revived after communism (Pabian et al. 2011). This was reflected in the institutionalization of external buffer organizations and strong student participation (Dobbins 2011a). The Czech Rectors' Conference-founded in 1993 - and Council of Higher Education Institutions (Rada vysokých škol) were established to formally represent academic senates and faculties. The Council also comprised students, and subsequently, a Student chamber of the Council was created to formally advocate students' interests vis-à-vis the state.

\section{Hungary}

After 1948, the communists completely transformed Hungarian HE. University autonomy was abolished, technological and cadre training were preferred over liberal arts and social sciences, and the participation of students of a worker and peasant background massively expanded (Murray 1960, 399-402). The Petôfi Circle, an intellectual club of the communist youth organization, played a prominent role in the internal party opposition during the restoration attempt of the Stalinist faction between 1954 and 1956. Students, alongside industrial workers, comprised the backbone of the October-November 1956 armed struggle against the communism. In fact, it was the 23 October solidarity march with Poland of the students of the Budapest University of Technology that started the revolution (Rainer 2016). After bloody retaliations, the regime took a national-accommodative character, but Kádár's "Goulash communism" was never lenient towards student's initiatives outside the Federation of Communist Youth (KISZ_Kommunista Ifjúsági Szövetség) (Ungváry 2007). After 1968 though, new colleges for advanced studies became small islands of democracy, while training the country's academic, political and economic elite.

The 1985 Education Act authorized the founding of independent student selfgovernments. Students thus soon formed the National HE Interest Representation Federation (OFÉSZ_Országos Felsöoktatási Érdekképviseleti Szövetség) in 1988, which also comprised anti-communist faculty (Kucsera 2010, 38-39). Other academic organizations were formed during the turbulent years of 1988-1989 (Labanino et al. 2021), including the Rectors' Conference, the main HE and academic unions (along with the labour union federation of such unions). In 1996, the main student organization, the OFÉSZ, became the National Conference of Student SelfGovernments (HÖOK-Hallgatói Onkörmányzatok Országos Szövetsége), which has been ever since formally stipulated by law as main student interest representation (Kucsera 2010). The Rectors' Conference and the National Federation of Doctoral Students (DOSZ_Doktoranduszok Országos Szövetsége) also were granted formal legal status in 1993 and 2011, respectively.

\section{Slovenia}

Yugoslavia's move away from Stalinism in 1948 was reflected in Slovenian student and academic activism. Many young people identified with the socio-economic system and wished to shape it (Ule 1998). The Slovenian student movement had weaker 
dissident roots and instead was largely inspired by western leftist student movements in 1968 and later (see Čepič 2018). While indeed demanding more individualism and decentralization, their activities were mainly directed against American and Soviet foreign policy. Yugoslav and Slovenian social scientists also established the Praxis School, which was ideologically rooted in Marxism and the western "New Leftist" movement. Thus, both academic and students' movements primarily advocated humane and participative socialism (Ramšak 2015; Čepič 2018). This resulted in numerous corporatism-oriented changes to university governance, most notably, a tripartite arrangement of faculty and university bodies including university staff, faculty and external (i.e. political) representatives (Ule 2015). However, this simultaneously heralded more political control, resulting in the 1970s in crackdowns on student protests and targeted state support for socialist youth movements.

Student and academic movements were at the forefront of the anti-communist resistance, decisively contributing to the system's collapse. Slovenian students and academics particularly supported the notion of statehood based on Slovenia's "radically different" character than the rest of Yugoslavia (Hansen 1996, 484). However, the university governance model became rather one-sided, no longer reflecting the previous tripartite arrangement. Only tenured professors participated in academic senates (Zgaga 2002), while students and other academics were excluded. Yet students created the Slovenian Student Union as an umbrella organization in 1994, which only began operating nationally and without a formal status in $2002 .{ }^{1}$ Unlike the other analysed countries, Slovenian rectors only established an organization in 2005. However, Slovenia entered the post-socialist phase with an already well-developed landscape of more discipline-specific academic and student organizations and experienced a proliferation of new students' and university employees' organizations in the mid-1990s (Labanino et al. 2021). By the late 1990s, it also introduced more inclusive academic senates and an academic assembly at all universities consisting of all key stakeholders (Zgaga 2002).

After reflecting on the historical context, our data now not only allows us to explore the position of students and various other HE groups (university rectors, workers, academics) nowadays, but also assess whether these systems gravitate towards pluralist or corporatist interest intermediation. While other authors have pointed to more pluralist policy-making in CEE (for HE, see Klemenčič 2014) ${ }^{2}$ and lacking corporatist structures and social dialogue (Jahn 2016), we argue that postcommunist HE systems may indeed be an anomaly. First, mass academic and student mobilization was decisive in dismantling communism, resulting in a widespread sentimental attachment to academics and students in CEE, which may in turn enable them privileged access to the state. Second, the phase of post-communist "path initialization" may continue to reverberate. Academic groups were extremely quick to gain a grip, or even a monopoly on policy-making, by creating buffer institutions enabling them to self-manage the policy area. Third, Bologna and its heavy focus on

\footnotetext{
1 https://www.studentska-org.si/predstavitev/english/about-ssu/.

2 Klemenčič postulates that transitional countries generally opt for a pluralist approach, because this enables governments to "divide and rule" rivaling groups.
} 
Table 1 Types of organizations by country

\begin{tabular}{lcccccccc}
\hline & CZ 2018 & CZ 1989 & HU 2018 & HU 1989 & PL 2018 & PL 1989 & SLO 2018 & SLO 1989 \\
\hline HE scientific & 19 & 10 & 23 & 15 & 17 & 12 & 29 & 12 \\
HE students & 12 & 1 & 12 & 5 & 15 & 5 & 44 & 4 \\
$\begin{array}{l}\text { HE institu- } \\
\text { tions }\end{array}$ & 7 & 0 & 8 & 3 & 5 & 1 & 1 & 0 \\
HE employees & 3 & 0 & 6 & 6 & 2 & 2 & 5 & 1 \\
\hline
\end{tabular}

Own elaboration

stakeholdership and student demands may have further consolidated inclusive and dialogue-oriented policy-making regimes. Hence, we assume that HE stakeholder regimes will gravitate towards the corporatist ideal-type characterized by a balancing of interests and dialogue-oriented policy-making. Yet our data also allow us to address - in line with Klemenčič's (2014) argument-the degree of pluralist competition between rivalling groups and hence whether pluralist elements exist (or have increased during the Bologna Process) within otherwise presumably corporatist systems. We now outline our multi-step approach to test these assumptions.

\section{Analysis}

We conducted an online survey targeting all national-level HE organizations in the four countries. The survey also included organizations operating in energy and healthcare policy (see below). All organizations were identified by searches in court registries $^{3}$ and included both state-licensed (e.g. rectors' conferences) and nonlicensed interest groups. An overview of the types of organizations and their proliferation between the collapse of communism (1989) and the present (2020) is provided in Table 1.

The multiple-choice survey questions with a comment option addressed their interactions with parties, parliaments, regulatory authorities as well as policy coordination with the state. The survey was administered between March 2019 and May 2020 in the four national languages. Organizations perceived as critically important (e.g. major students' organizations, large labour unions consisting of university workers, rectors' conferences) were contacted more intensely and nearly all responded to the survey. We received approx. 90 responses, covering essentially all "encompassing" ${ }^{4}$ organizations (e.g.

\footnotetext{
${ }^{3}$ For Poland, the National Court Registry (Krajowy Rejestr Sadowy-KRS), for Hungary the court registry of civil society organizations (Civil szervezetek névjegyzéke), for Slovenia the AJPES registry (Agency of the Republic of Slovenia for Public Legal Records and Related Services) and for the Czech Republic the registry of the Czech Statistical Office.

4 We borrow Olson's term "encompassing organizations" (1965/1982) to demarcate larger organizations, often of an umbrella character, who represent large segments of the HE sector (e.g., national students' organizations, national rectors' conferences, nationally operating HE workers' unions) as opposed to more specialized interests (e.g. medical students, university librarians, geography association, etc.).
} 
rectors' organizations, general students' organizations, university workers' associations). ${ }^{5}$

The advantage of the survey is that it provides authentic insights from interest organizations regarding their position in the policy-making process. However, survey data bear the disadvantage of subjectivity. Organized groups may exaggerate or underestimate their own recognition by the state and involvement in policy consultations. Nonetheless, our relatively large sample of responding organizations representing heterogeneous interests enables us to partially overcome potentially biased responses. Moreover, to increase the "authenticity" of our data and compensate for the few cases of non-response by large organizations, we gathered data from national parliaments, HE consultation bodies and secondary literature. We also conducted 11 interviews with HE stakeholder representatives and policy experts (see "Appendix").

\section{Exploring policy styles in CEE HE}

Roughly following Vukasović (2018), we categorized all responding organizations into subgroups: general students, discipline-specific students (e.g. law, medicine), professional academic organizations (e.g. sociology, linguistics), ${ }_{6}^{6}$ university workers (i.e. labour unions) and organizations representing HE institutions (i.e. rectors' conferences, university sector lobby associations). Although not traditional interest organizations, we included academies of science in our survey as they may function as important general representations of academic researchers. This reflects the particular history of CEE, where research was generally concentrated in academies of science, while universities were chiefly teaching institutions. As already described, our specific category of "encompassing organizations" covers large organizations representing students, sectoral interests (e.g. rectors' conferences, university sector lobby associations), university workers and the academic profession (e.g. academies of science) as a whole (see endnote 3).

First, we were interested whether corporatist-like structures exist to support "stakeholder democracy" nowadays. We define several "ingredients" of corporatist, consensus-oriented policy-making to conceptually grasp forms of interaction. In economic policy and beyond, corporatism generally entails the transfer of policymaking from the parliament to institutionalized platforms for exchange between larger peak or encompassing organizations and strong political coordination between the state and organized interests. This is expected to lead to a distinct consensus orientation and relatively equal representation of "diffuse" (e.g. students) and "concentrated" interests (e.g. rectors). Thus, we asked:

\footnotetext{
5 The numbers in Table 1 reflect all contacted organizations, including very specific organizations contacted less intensely (e.g., geography students association, Association of Byelorussian students in Poland).

${ }^{6}$ We relied on Wikipedia's list of broader academic disciplines, https://en.wikipedia.org/wiki/Outline_ of_academic_disciplines. For example, general historical or philosophical associations were included, but not specific organizations such as "The Association of Eastern European Historians" or "The Association of Platonic Philosophy". We also narrowed the population to organizations with active university personnel and mentions of $\mathrm{HE}$ and science policy or university research on their website.
} 


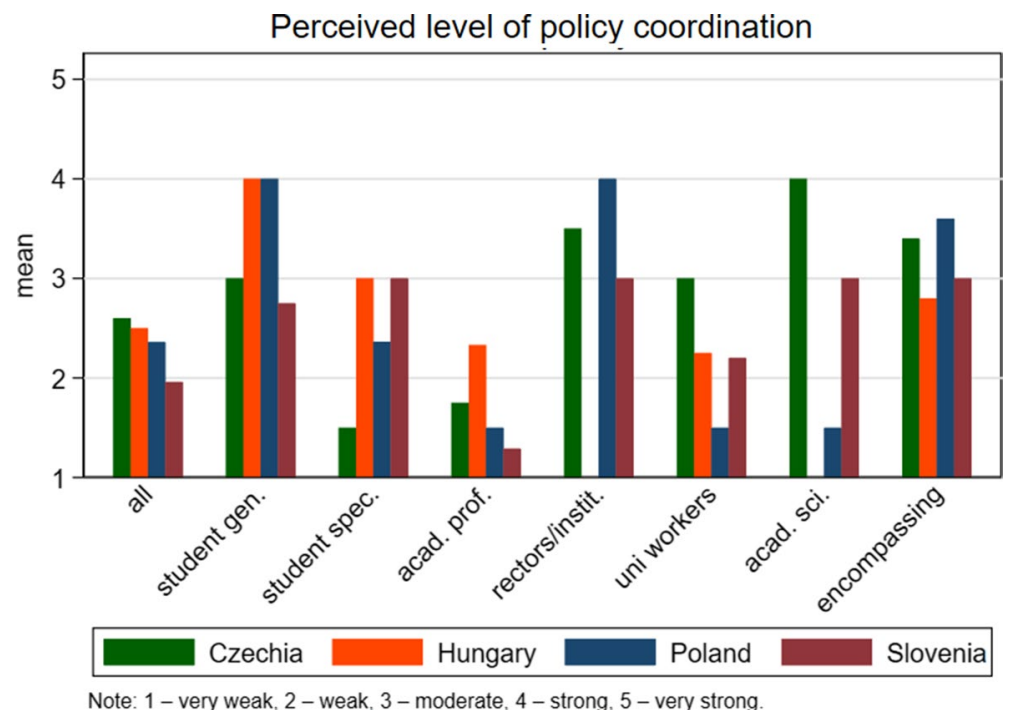

Fig. 1 Perceived level of policy coordination

How would you rate the level of policy coordination/political exchange between the state and your interest group?

Here, general student organizations reported moderate to strong policy coordination in all countries. However, in contrast to Jahn's (2016) high corporatism ranking for Slovenia, general student groups report low coordination, which is compensated by specific groups (e.g. medicine, law, etc.). Rectors and university associations also report moderate to strong coordination, while university workers - as is generally the case with employees' associations in CEE (Vanhuysse 2007)—perceive policy coordination as weaker. In fact, for Poland, numerous other organizations indicated the rectors' organization as the main and/or sole mouthpiece for university interests (Interview PL-2) (Fig. 1).

We then explored the aggregate perception of ties between HE stakeholders and political parties:

Approximately how often does your organization consult with political parties?

Polish students - unlike rectors and representatives of institutions-report much weaker ties with political parties than their Czech, Hungarian and Slovenian counterparts. In general, the data point to relatively low partisan politicization of HE, with the exception of Hungary (and Poland, see below). This finding for Hungary seems to contradict the claims of infringement on academic freedom and democratic backsliding (Sata and Karolewski 2020) under Orbán. However, these high scores for consultations among general student and encompassing HE organizations are driven mostly by academic organizations stipulated by law as formal public bodies and financed by public sources. Thus, they are consulted regularly and/or have 


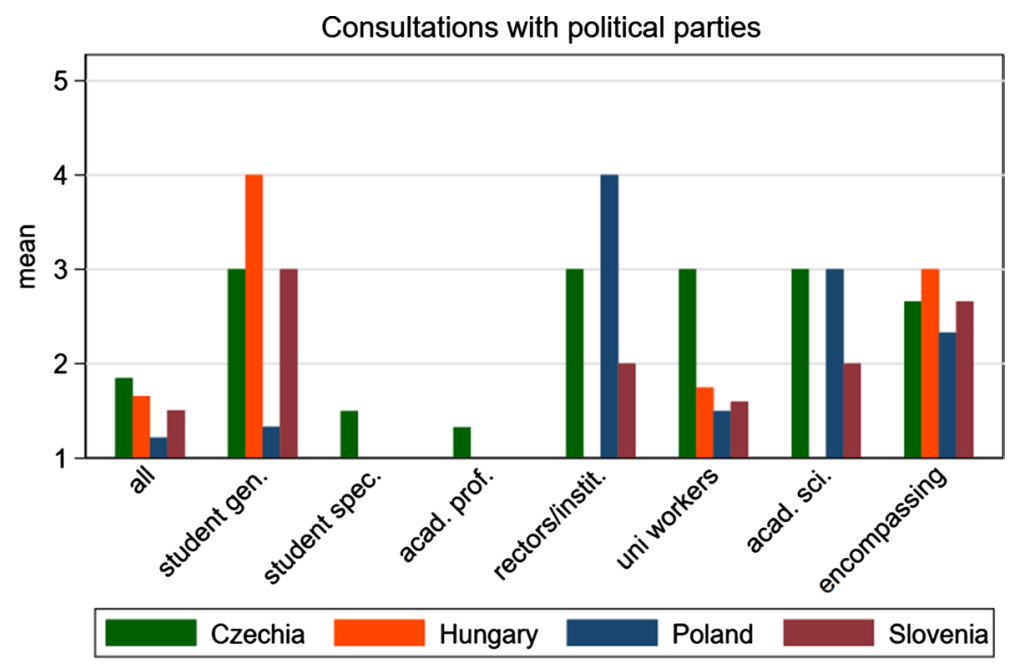
Note: 1 - never, 2 - (approx.) annually, 3 - (approx.) twice a year, 4 - (approx.) monthly,
5 - (approx.) weekly.

Fig. 2 Consultations with political parties

been co-opted by the government. During the winter of 2012 and 2013 after an announcement of a radical reduction in state-financed university student places, the government faced a rare unified front of such established organizations as the Rectors' Conference and the main student organization and new, grassroots students' and lecturers' organizations. In response, the government co-opted the former-and the main HE union-and made concessions regarding the number of state-financed university students, but went forward with its university finance and governance reforms anyway (Labanino and Dobbins 2020). We interviewed high-level representatives of two such established, public bodies, the Rectors' Conference ${ }^{7}$ and the National Association of Doctoral Students. Both emphasized their good professional relations and access to the decision-makers as well as regular consultations (Interviews HU-3, HU-5). Yet it is telling that Hungarian academic professional organizations and university workers' organizations reported no or very weak access to parties (Fig. 2).

We also asked about the intensity of consultations with the present and previous governments:

Approximately how often does the (present/previous) government consult interest groups in your field of activity?

Our data show that biannual to monthly consultations between large, general HE stakeholders (i.e. encompassing organizations) and political parties are the norm. However, Czech and Polish rectors as well as Polish and Hungarian students are outliers, engaging very frequently in consultations. In line with the corporatist

\footnotetext{
7 We do not have a survey response from this organization, rather relied on the interview.
} 


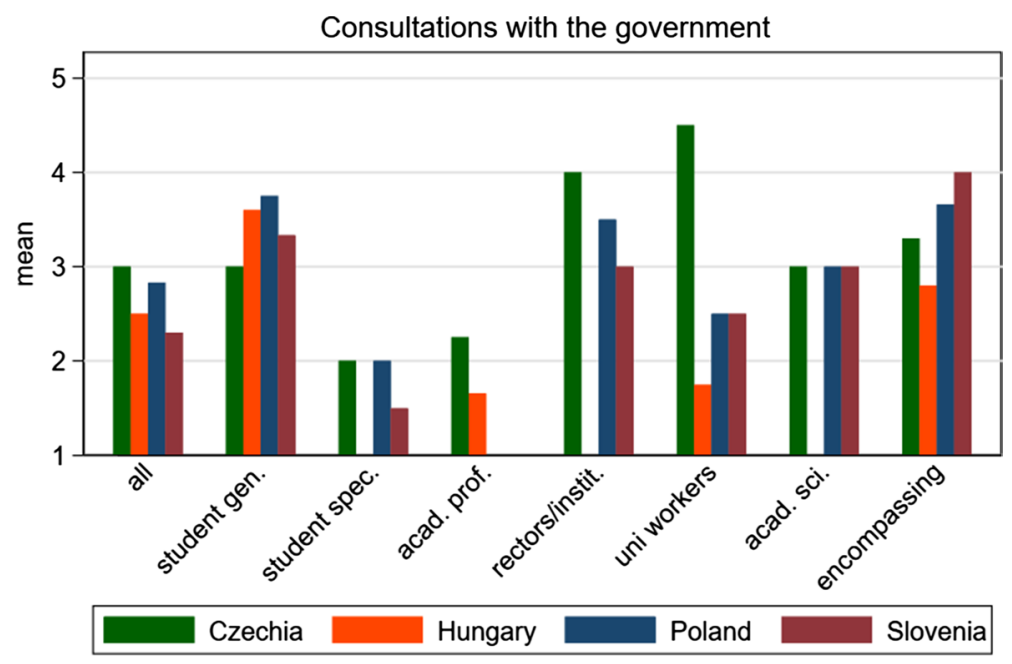

Note: 1 - never, 2 - (approx.) annually, 3 - (approx.) twice a year, 4 - (approx.) monthly, 5 - (approx.) weekly.

Fig. 3 Consultations with the government

paradigm, encompassing organizations in all four countries report frequent consultations, with Hungary being a partial exception (Fig. 3).

Assuming that corporatist interest intermediation arrangements remain stable over time, we compared the intensity of consultations between the present governments ${ }^{8}$ and previous governments ${ }^{9}$ (Fig. 4).

Aside from the missing data from Hungary, where today's students were mostly small children under the previous coalition (up to 2010) and Czech rectors, who reportedly cultivate closer ties with the present Babiš government, the results almost mirror those of the present governments. In Poland, students report closer ties with the present national-conservative government (also Interview PL-3), whereby the academic profession groups report closer contacts with previous liberal-conservative government. The results for the major encompassing organizations, however, point to relative stability.

This sheds light on another interesting aspect, considering that previous governments now generally constitute the political opposition (with the partial exception of the Czech ANO government): the relatively similar frequency of contacts with governing and opposition parties reflects the relatively low level of politicization of $\mathrm{HE}$ in the region (with the partial exception of Hungary, see below).

\footnotetext{
${ }^{8}$ Poland=the moderately national-conservative PiS government, 2015-present; Hungary =the strongly national-conservative Fidesz government, 2010-present; Slovenia=the center-left LMŠ (Lista Marjana Šarc), 2018-March 2020; Czech Republic = the liberal Ano/Social Democratic ČSSD government, 2018-present.

9 Poland=Civic Platform (PO) (2007-2015); Hungary = socialist MSZP - liberal SZDSZ (2004-2010); Slovenia $=$ center-right SDS (2014-2018); Czech Republic $=\breve{C S S D / A n o ~ \& ~ C h r i s t i a n ~ D e m o c r a t i c ~ K D U-~}$ ČSL (2014-2018).
} 


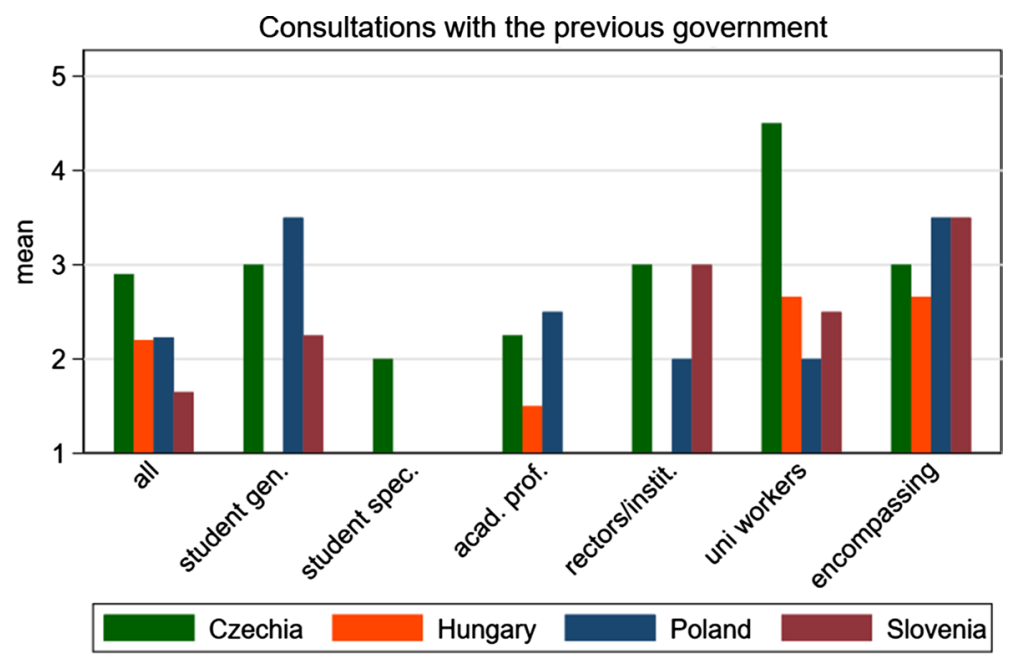

Note: 1 - never, 2 - (approx.) annually, 3 - (approx.) twice a year, 4 - (approx.) monthly, 5 - (approx.) weekly.

Fig. 4 Consultations with the previous government

Indeed, numerous responding organizations from all four countries explicitly reported that they maintain frequent contacts with all major political parties, without expressing a particular preference.

We also asked about interactions between interest groups and regulatory authorities (specifically quality assurance and accreditation bodies) to assess to what extent policy-making takes place outside traditional political channels.

Approximately how often does your organization consult with regulatory authorities in HE?

The data reflect a transfer of policy-making to quality assurance and evaluation agencies, in which major stakeholder groups, most notably rectors and studentsand professional academic organizations in the Polish case-take a central position. And again here, we observe a heavy presence of students and organizations representing universities (i.e. rectors) (Fig. 5).

In line with our understanding of corporatism as the balancing of rivalling interests, we also asked all organizations:

Do you think that opportunities for participation are equally distributed among interest organizations?

The general tenor is a relatively equal playing field with little country variation. Notable, however, is the weaker position of university workers' associations and specific professional academic organizations (e.g. geography, law). In particular in Poland and the Czech Republic, it seems that rectors' associations function as a mouthpiece of the universities to the detriment of smaller specific organizations (see Vlk et al. 2021; Interview PL-2) (Fig. 6). 


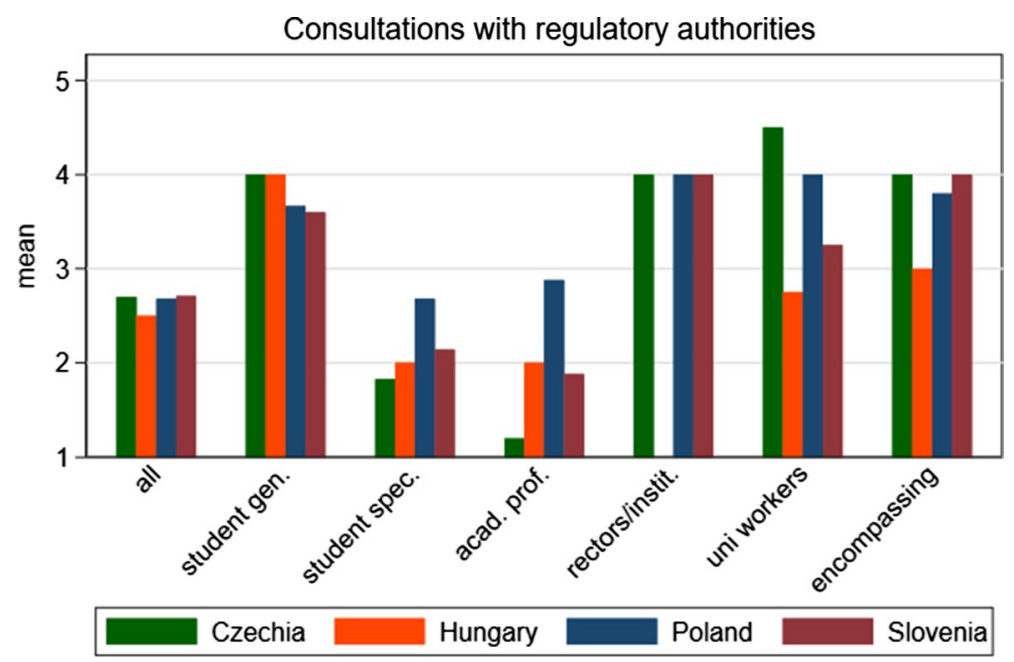

Note: 1 - never, 2 - (approx.) annually, 3 - (approx.) twice a year, 4 - (approx.) monthly, 5 - (approx.) weekly.

Fig. 5 Consultations with regulatory authorities

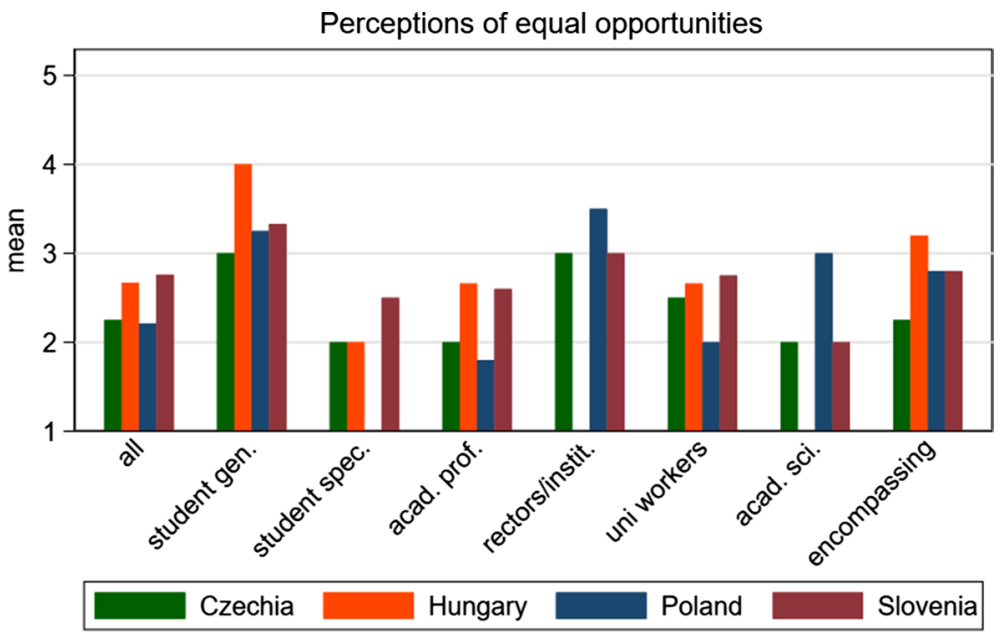

Note: 1 - very much to the favor of other organizations, 2 - somewhat to the favor of other organizations, 3 - equally distributed, 4 - somewhat to the favor of our organizations, 5 - very much to the favor of our organizations.

Fig. 6 Perception of equal opportunities

To better demarcate corporatism from pluralism and understand the factual situation, we took two further steps. First, we are interested in the extent to which organizations compete for the same constituents. Strong competition would indicate the existence of rivalling organizations and thus a "pluralist" struggle over representativeness for certain stakeholders. We asked: 


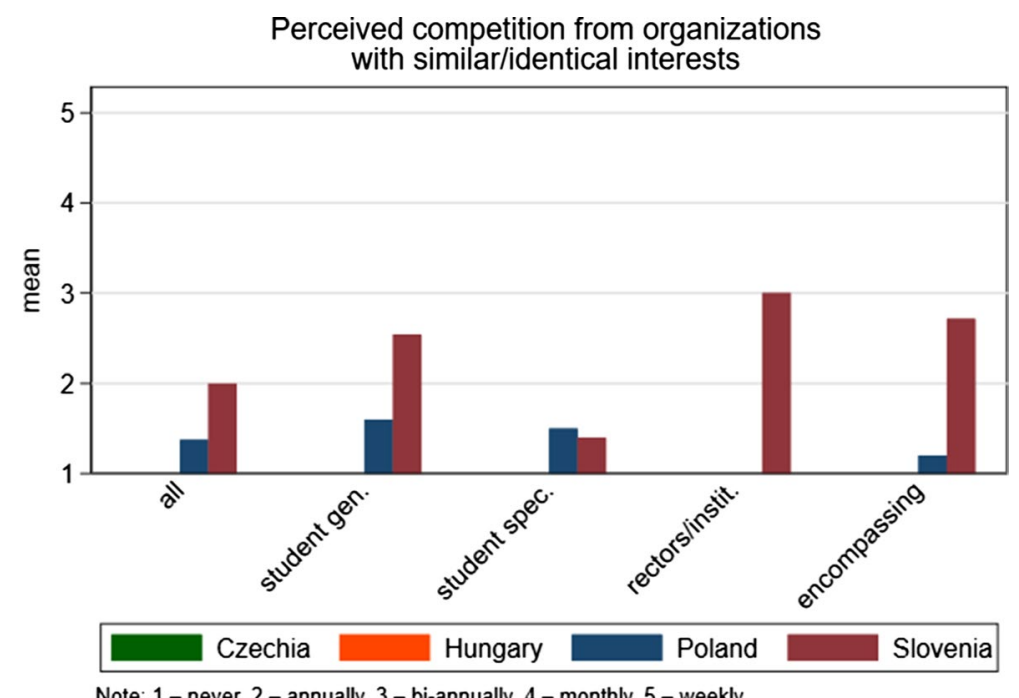

Note: 1 - never, 2 - annually, 3 - bi-annually, 4 - monthly, 5 - weekly.

Fig. 7 Perceived competition from organizations with similar/identical interests

Do you experience intensive competition from organizations representing similar/identical interests and values?

The results point in a corporatist direction, with the special case of Slovenia (see below), and to some extent Poland. However, a word of strong caution is warranted. Among all questions asked, this question delivered by far the lowest response rate (approx. 30\%), of which the large majority of respondents were Slovenian organizations. However, we believe it is justifiable to assume that non-response is indicative of low competition over constituents, as non-responding organizations are likely to be simply unaccustomed to competition with similar organizations seeking advocacy monopolies over the same constituents. Unless otherwise noted in the survey comments, we hence coded non-responding organizations as perceiving no competition $^{10}$ (Fig. 7).

Looking back, we have established that HE policy-making in the four countries bears numerous features of the corporatist paradigm and that relative parity in the intensity of consultations and policy coordination exists, at least between larger encompassing organizations. We also see evidence of general students' organizations being as equally well integrated into policy-making as organizations representing university interests (i.e. rectors). However numerous questions remain open: how stable have these arrangements been over time? Have there been any notable changes since Bologna (Vukasović 2018)? And are the country-specific arrangements really

\footnotetext{
${ }_{10}$ Academies of Science and specific scientific organizations were dropped because they essentially stand alone.
} 


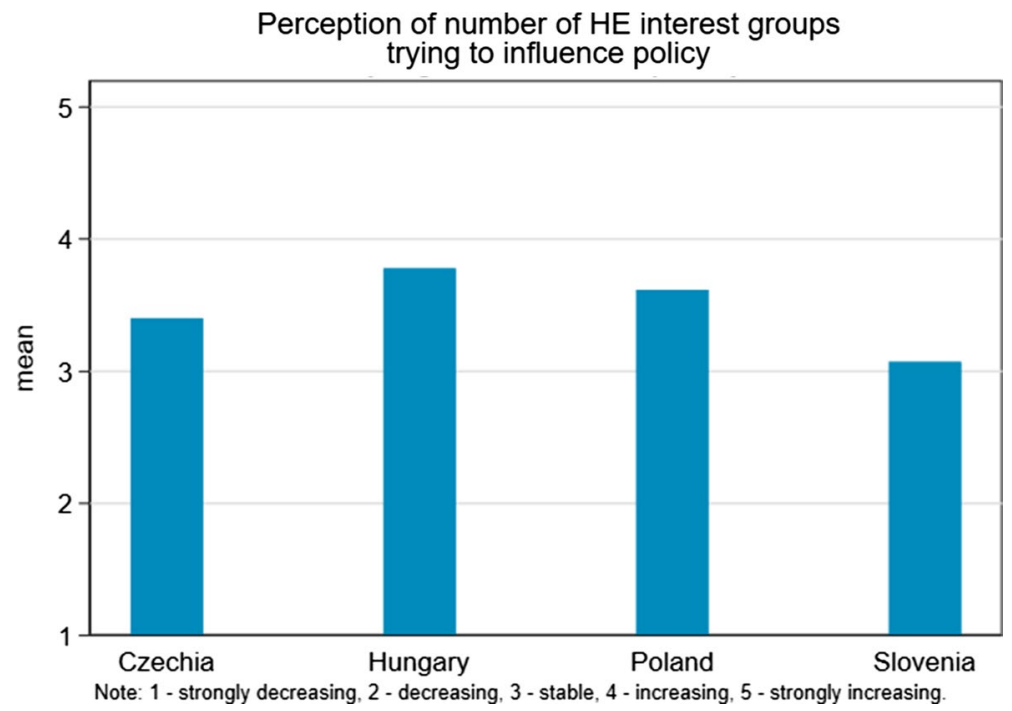

Fig. 8 Perception of number of HE interest groups trying to influence policy

as similar as our aggregate data would lead us to believe? Our dataset enables us to comparatively address these questions (Fig. 8).

We asked all organizations:

In your opinion, is the number of interest organizations attempting to influence legislation in your area increasing, decreasing or stable over the past 10-15 years?

Here we observe relative stability in Slovenia, the country which already exhibited a pluralistic pre-transformation interest group landscape, while organizations from the other countries report a slight increase in HE stakeholder groups. We also inquired:

How has the size of your organization's membership changed in the past $10-15$ years?

Here we see the persistent weakness of workers' organizations, which falls in line with a broader observation for CEE, where workers movements were unable to adapt to the capitalist economic order (Ost 2011). By contrast, students' and rectors' organizations (with the partial exception of Slovenia) are maintaining steady growth. And while we see a shift towards encompassing organizations in the other countries, Slovenia - the country generally attested a higher level of corporatism (Jahn 2016)_again counters this trend. The data show a strong increase in student activism in Hungary, reflected in booms in membership of general and specific student groups, as well as an increase in membership in professional academic groups. We would attribute this increase to the radical, systemic changes of the past turbulent decade. The new $2011 \mathrm{HE}$ Act together with the introduction the dual governance system of universities in 2014-2015 (Kováts 2015) reduced institutional autonomy and academic self-regulation (see, for example, EUA 2017; Polónyi 


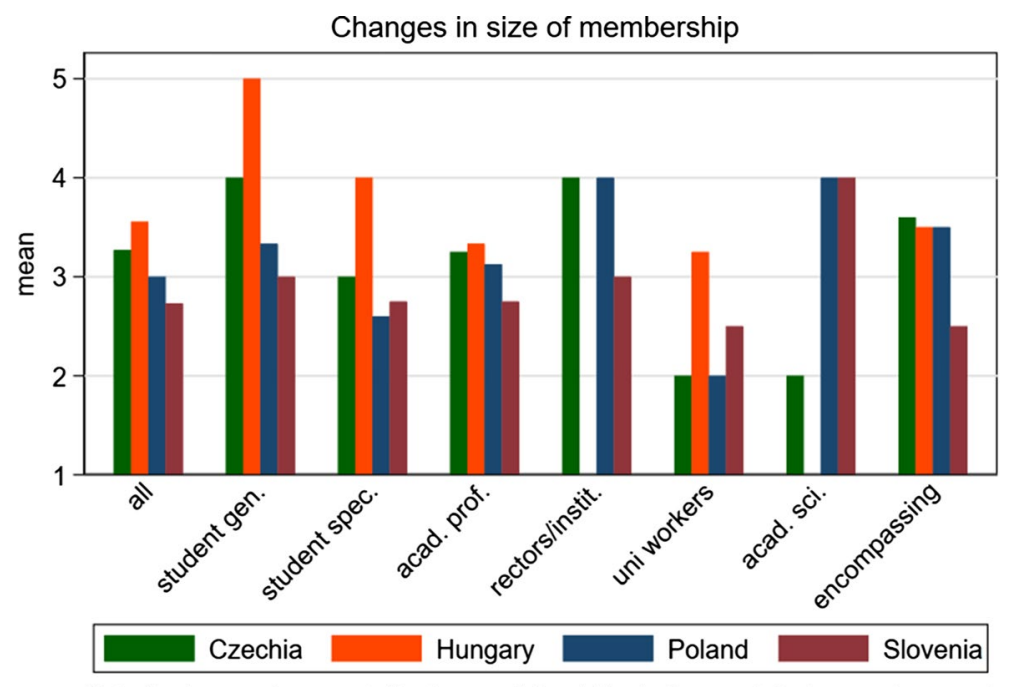

Note: 1 - decreased very much, 2 - decreased, 3 - stable, 4 -increased, 5 - increased very much.

Fig. 9 Changes in size of membership

2015). Furthermore, other swiftly and unilaterally introduced measures such the withdrawal of the accreditation of gender studies, the encroachments on the Central European University and the governmental takeover of the renowned research institute network of the Hungarian Academy of Science followed one another in the past 10 years (Labanino and Dobbins 2020) (Fig. 9).

Academies of science and professional academic organizations have also indeed increased their membership in Poland and Slovenia. ${ }^{11}$ For Poland, we would interpret this is as a result of the state's increased focus on re-institutionalizing competitive academic research, which suffered from a myriad of structural and financial obstacles post-1990. Efforts to reinvigorate fundamental research with new funding incentives and initiatives are likely to have boosted organizational membership (Dobbins 2017).

Finally, we asked all organizations how they assess their ability to assert their interests compared to 10 years ago:

To what extent do you assess the ability of your organization to assert its interests as opposed to 10-15 years ago (or since its founding, if founded more recently)?

Again, we see picture of relative stability, but also further confirmation of numerous arguments presented above. First, the graphic reflects greater strength of student organizations (with Poland as a slight exception), likely an effect of the Bologna Process, which specifically promoted direct student engagement (Vukasović 2018). We also see a strengthening of rectors' and institutional organizations promoting

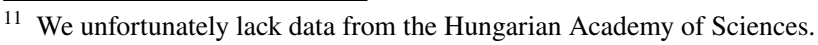




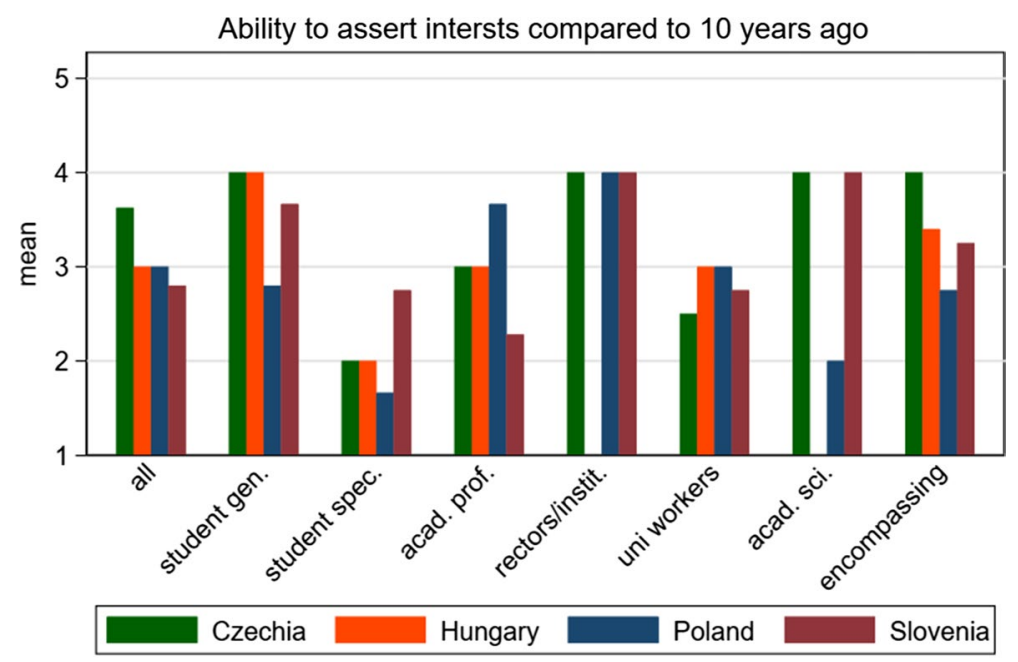

Note: 1 - much less than before, 2 - less than before, 3 - the same, 4 -greater now, 5 - much greater now.

Fig. 10 Ability to assert interests compared to 10 years ago

broader university interests. From the perspective of corporatist vs pluralist-style policy-making, the data reveal no shift away from encompassing organizations as the major stakeholders. And again, following the broader trend in the region, employees' unions have not gained traction (Fig. 10).

\section{Comparing HE with other policy areas}

While our data show relatively strong stakeholder engagement and corporatist tendencies, in particular among students, rectors' organizations and large academic associations (i.e. academies of science), they still bear two major weaknesses. First, we still do not know how HE organizations fare against those operating in other policy areas. Second, our standardized dataset only partially grasps all country-specific nuances of corporatism. Therefore, we wrap up the analysis by testing whether HE organizations enjoy "privileged proximity" to policy-makers over non-HE organizations and then provide some additional descriptive analysis of HE stakeholder arrangements in CEE.

This time we focus on access to the policy-makers, and specifically whether differences can be attributed to whether organizations operate in a specific policy area or specific country. Our dataset also including energy and healthcare organizations allows us to assess whether HE policy-making is "special" (see Table 2 for response rate by country and policy).

To trace differences across policy fields, we looked at three avenues of access-to the parliament, government and regulatory authorities. Our survey questions were straightforward: 
Table 2 Response rate per country in HE, energy (EN) and healthcare (HC) policy

\begin{tabular}{|c|c|c|c|c|}
\hline Country & Total responses & $\begin{array}{l}\% \text { of total } \\
\text { responses }\end{array}$ & $\begin{array}{l}\text { Total invited organiza- } \\
\text { tions per country }\end{array}$ & $\begin{array}{l}\text { Total } \\
\text { response rate } \\
\text { in } \%\end{array}$ \\
\hline Czechia-total & 123 & 28.3 & 366 & 33.6 \\
\hline CZ-HE & 18 & & 41 & 43.9 \\
\hline CZ-EN & 37 & & 106 & 34.9 \\
\hline $\mathrm{CZ}-\mathrm{HC}$ & 26 & & 71 & 36.6 \\
\hline Hungary-total & 97 & 22.3 & 275 & 35.3 \\
\hline HU-HE & 18 & & 49 & 36.7 \\
\hline HU-EN & 26 & & 71 & 36.6 \\
\hline HU-HC & 53 & & 155 & 34.2 \\
\hline Poland-total & 97 & 22.3 & 395 & 24.6 \\
\hline PL-HE & 26 & & 37 & 70.2 \\
\hline PL-EN & 25 & & 102 & 24.5 \\
\hline PL-HC & 46 & & 256 & 18.0 \\
\hline Slovenia-total & 118 & 27.1 & 228 & 51.8 \\
\hline SLO-HE & 38 & & 81 & 46.9 \\
\hline SLO-EN & 30 & & 46 & 65.2 \\
\hline SLO-HC & 50 & & 101 & 49.5 \\
\hline Total—all policy fields & 435 & 100 & 1264 & 34.4 \\
\hline
\end{tabular}

Own elaboration

How difficult is it for your organization to access regulatory authorities/the parliament/the governing party? (1-extremely difficult, 2-difficult, 3sometimes possible, 4-easy, 5-extremely easy)

For each form of access, we also controlled not only for individual countries, but also the impact of organizational membership, employees, financial stability and the status as an encompassing organization. We assume that organizations with greater financial and personnel resources as well as encompassing organizations will more easily access decision-makers. Hence, the approach enables us to assess whether merely being a HE organization is a greater determinant of access than organizational resources (i.e. finances, members, staff).

The variables regarding membership and employees were logged to prevent distortion and extreme values. Both variables represent added values: the variable employ is constructed by adding staff and volunteers as we are interested in the sum of the manpower of organizations. A similar logic applies for "membership", for which we calculated the absolute number of members by adding individual, firm and institutional numbers, i.e. the size of the organization (both transformed into a logarithmic scale due to extreme values). Assuming that organizations may be hesitant to reveal concrete financial data, we asked a less straightforward question, namely whether organizations are financially stable for "less than one year", "one to two years", "three to five years", "approximately five years" or "more than five years". 
Table 3 Access to the parliament, regulatory authorities and government parties (ordinal logistic regression-countries indicated as categorical variables)

\begin{tabular}{|c|c|c|c|c|c|c|}
\hline & $\begin{array}{l}\text { Parlaccess } \\
\text { (1) }\end{array}$ & $\begin{array}{l}\text { Parlaccess } \\
\text { (2) }\end{array}$ & $\begin{array}{l}\text { Regaccess } \\
\text { (1) }\end{array}$ & $\begin{array}{l}\text { Regaccess } \\
\text { (2) }\end{array}$ & $\begin{array}{l}\text { Govpaccess } \\
\text { (1) }\end{array}$ & $\begin{array}{l}\text { Govpaccess } \\
\text { (2) }\end{array}$ \\
\hline $\begin{array}{l}\text { Policy } \\
\text { field—HE }\end{array}$ & $\begin{array}{l}-0.39 \\
(0.27)\end{array}$ & $\begin{array}{l}-0.67 * \\
(0.34)\end{array}$ & $\begin{array}{l}0.83^{* *} \\
(0.30)\end{array}$ & $\begin{array}{l}0.79^{*} \\
(0.32)\end{array}$ & $\begin{array}{l}0.76^{*} \\
(0.33)\end{array}$ & $\begin{array}{l}0.69^{+} \\
(0.35)\end{array}$ \\
\hline $\begin{array}{l}\text { Czechia- } \\
\text { reference }\end{array}$ & & $\begin{array}{l}0.00 \\
(.)\end{array}$ & & $\begin{array}{l}0.00 \\
(.)\end{array}$ & & $\begin{array}{l}0.00 \\
(.)\end{array}$ \\
\hline Hungary & & $\begin{array}{l}-1.21^{* *} \\
(0.40)\end{array}$ & & $\begin{array}{l}-0.47 \\
(0.33)\end{array}$ & & $\begin{array}{l}-0.72^{+} \\
(0.42)\end{array}$ \\
\hline Poland & & $\begin{array}{l}1.13 * * \\
(0.34)\end{array}$ & & $\begin{array}{l}-0.38 \\
(0.34)\end{array}$ & & $\begin{array}{l}-0.28 \\
(0.37)\end{array}$ \\
\hline Slovenia & & $\begin{array}{l}-0.42 \\
(0.37)\end{array}$ & & $\begin{array}{l}0.02 \\
(0.34)\end{array}$ & & $\begin{array}{l}-0.55 \\
(0.35)\end{array}$ \\
\hline $\begin{array}{l}\text { Members } \\
\text { (logged) }\end{array}$ & & $\begin{array}{l}0.10^{+} \\
(0.06)\end{array}$ & & $\begin{array}{l}0.01 \\
(0.05)\end{array}$ & & $\begin{array}{l}0.09^{+} \\
(0.06)\end{array}$ \\
\hline $\begin{array}{c}\text { Employees } \\
\text { (logged) }\end{array}$ & & $\begin{array}{l}0.14 * \\
(0.07)\end{array}$ & & $\begin{array}{l}-0.10 \\
(0.06)\end{array}$ & & $\begin{array}{l}0.01 \\
(0.07)\end{array}$ \\
\hline $\begin{array}{l}\text { Financial } \\
\text { stability }\end{array}$ & & $\begin{array}{l}-0.11 \\
(0.09)\end{array}$ & & $\begin{array}{l}0.04 \\
(0.08)\end{array}$ & & $\begin{array}{l}0.10 \\
(0.09)\end{array}$ \\
\hline $\begin{array}{l}\text { Encompass- } \\
\text { ing org }\end{array}$ & & $\begin{array}{l}0.90^{* *} \\
(0.31)\end{array}$ & & $\begin{array}{l}0.71 * \\
(0.31)\end{array}$ & & $\begin{array}{l}0.49 \\
(0.32)\end{array}$ \\
\hline cut1 & $\begin{array}{l}0.45^{* * *} \\
(0.13)\end{array}$ & $\begin{array}{l}1.05^{*} \\
(0.41)\end{array}$ & $\begin{array}{l}-1.09 * * * \\
(0.15)\end{array}$ & $\begin{array}{l}-1.25^{* *} \\
(0.39)\end{array}$ & $\begin{array}{l}-0.39^{*} \\
(0.15)\end{array}$ & $\begin{array}{l}0.13 \\
(0.41)\end{array}$ \\
\hline cut2 & $\begin{array}{l}1.86^{* * *} \\
(0.17)\end{array}$ & $\begin{array}{l}2.74 * * * \\
(0.44)\end{array}$ & $\begin{array}{l}0.53^{* * *} \\
(0.14)\end{array}$ & $\begin{array}{l}0.41 \\
(0.39)\end{array}$ & $\begin{array}{l}1.01 * * * \\
(0.17)\end{array}$ & $\begin{array}{l}1.60 * * * \\
(0.43)\end{array}$ \\
\hline Observations & 336 & 289 & 263 & 263 & 210 & 210 \\
\hline Pseudo $R^{2}$ & 0.004 & 0.127 & 0.014 & 0.034 & 0.012 & 0.040 \\
\hline
\end{tabular}

Standard errors in parentheses

${ }^{+} p<0.1, * p<0.05, * * p<0.01, * * * p<0.001$

We first conducted a bivariate correlation analysis of the access variables to determine to what degree our dependent variables are interrelated. We find a very strong correlation between access to government parties and regulatory bodies for all organizations. However, for the subsequent regressions we stick to the distinction between both types of access as they represent very different political venues. The former pertains to actual partisan political actors, whereas the latter comprises quality assurance and accreditation bodies consisting generally of both governmental policy-makers and members of the HE community. According to Table 3, parliamentary access stands out from the other two forms of access. This is highly useful for our purposes as corporatist arrangements are generally associated with the transfer of policy-making away from the parliament into other intermediate bodies.

For each type of access, we first conducted bivariate regressions to measure the effect of an organization's affiliation with the HE sector on access to governing parties, 
regulatory authorities and the parliamentary arena. We then conducted multivariate ordinal regressions for which we tested for country-specific effects while also controlling for members, employees, financial stability and whether the organizations are larger, encompassing organizations.

Table 3 shows the results. In the bivariate regressions, we assessed the ability of HE organizations to access national parliaments in comparison with healthcare and energy interest organizations. The bivariate calculations show that HE organizations are less likely to access the parliament, but enjoy better access to governing parties and regulatory authorities in their respective policy area than organizations operating in both other sectors. These findings are mirrored by the multivariate regressions, which control for numerous interest group-specific factors (members, employees and financial capacity). Again, we see that merely being a HE organization significantly enhances its ability to access the government and regulatory authorities compared to the healthcare and energy sectors.

By contrast, an organization's affiliation with the HE sector decreases its ability to access the parliamentary arena, lending evidence to the fact that HE policy (outside Poland) is conducted via tight channels between organized interests, governments and regulatory authorities. Particularly striking is the difference between Poland and Hungary. In Poland, all organizations report operating in the parliamentary arena very frequently, while their Hungarian counterparts appear to be shut out from the parliament. This coincides with other findings on Hungary, which show that the parliament has essentially become a relatively closed "law factory" without functional channels for stakeholder participation (Greskovits 2015; Sata and Karolewski 2020; Labanino and Dobbins 2020).

None of the control variables appear to have substantially enhanced access to the three analysed decision-making forums. Only being an encompassing organization, i.e. representing students, university workers, the university sector as a whole, somewhat enhances access.

Altogether, the results support our assumption that HE is different, more corporatist and stakeholder-driven in CEE, albeit somewhat more "parliamentarized" in Poland. Thus, HE organizations, in particular rectors and institutional representatives as well as large student and academic organizations, have comparatively well exploited their position as key players in bringing down communism to set up interest intermediate structures akin to stakeholder democracies.

However, aggregating organizations into groups (see above) and the large-scale statistical analysis have the major disadvantage that it is difficult to identify organizations with exclusive or monopolistic positions. Moreover, it is unclear whether and how country-specific stakeholder regimes have "mutated" in different directions. To address these weaknesses, we again draw on our dataset to identify potential representation monopolies, before discussing country-specific nuances in interest intermediation.

\section{Short descriptive overview of the four stakeholder regimes}

To assess the level of the presence of each organization in policy-making, we returned to our dataset and attributed each organization a score for the frequency 


\section{Share of all reported consultations by organization per year - Poland}

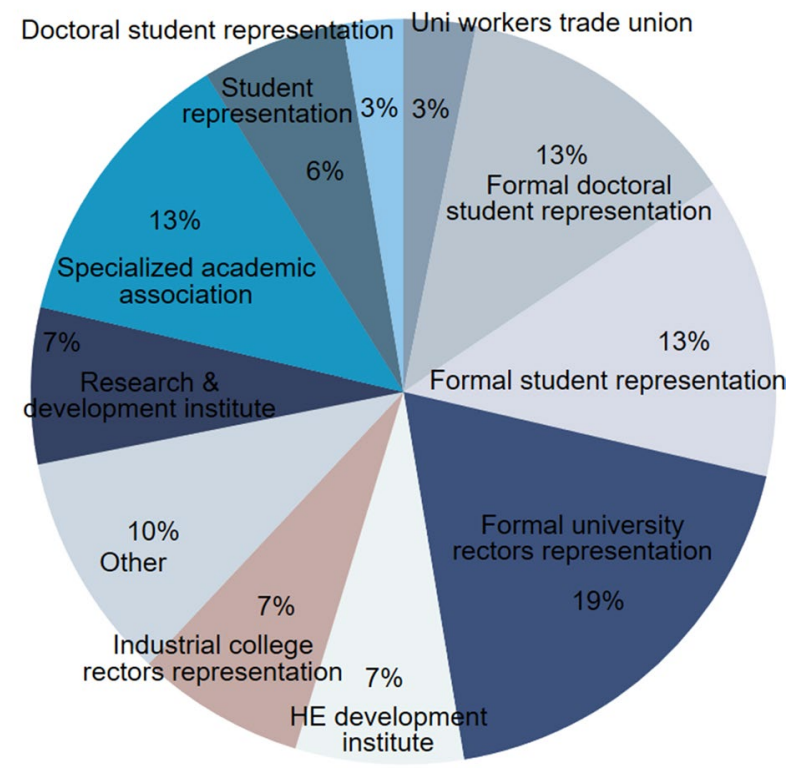

Source: own elaboration

Fig. 11 Share of consultations - Polish organizations

of consultations with governments, regulatory authorities and parties based on the totality of all consultations reported in our survey. We gave organizations engaging in annual consultations with governments, parties, and/or regulatory authorities one point each per type of consultation, for biannual consultations two points, for monthly consultations 12 points and for weekly consultations 52 points each to roughly reflect the frequency of actual consultations. For reasons of anonymity, the names of the organizations are rendered indirectly (see Figs. 11, 12, 13, 14).

For Poland, we see three state-licensed organizations comprising rectors and (doctoral) students accounting for around 45 per cent of all consultations, whereas other non-formal (doctoral) students' associations are also occasionally consulted. Altogether, this points in a corporatist direction, albeit with more openings for other organizations than the Czech case (see below).

Poland is also unique because two major students' advocacy organizations crucial in bringing about democracy-Niezależne Zrzeszenie Studentów (Independent Students' Association) and Zrzeszenie Studentów Polskich (Association of Polish Students)—quickly lost influence in the post-communist era. Poland has thus essentially experienced a "change of the guard" regarding student activism. The Parlament Studentów emerged as a (state-licensed and state-financed) body voicing students' interests with a fixed position in all major governance bodies, e.g. the High Council (Rada Główna), the Polish Accreditation Committee, as well as Sejm and Senate committees dealing with HE (Interview PL-3). The new conservative student 


\section{Share of all reported consultations by organization per year - Czechia}

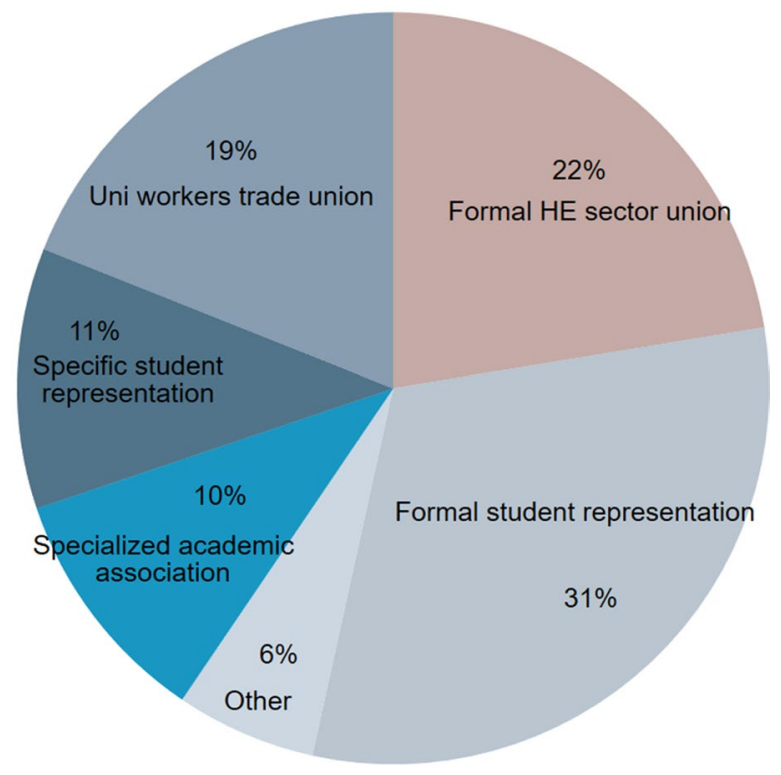

Source: own elaboration

Fig. 12 Share of consultations - Czech organizations

organization Studenci dla rzeczpospolity is also establishing itself as a key player and reports close ties with the Student Parliament and other student organizations, again reflecting a more corporatist policy style.

Characteristic of Poland is also the increasingly visible emergence of the Rectors' Conference as the main mouthpiece of university interests, both in the parliament and towards the government. Also state-licensed, it recently successfully mobilized for a concentration of power in university management and downgrading of representation of other university stakeholders (e.g. faculties, institutions, departments and professional academic groups). Thus, there are indications the pre- and postcommunist structures of academic democracy are evolving into a state-rector corporatist alliance which still enables active student participation (see Vlk et al. 2021).

Czech HE, by contrast, largely reflects the post-1990 status quo based on negotiations between the Ministry of Education and Council of HE Institutions (Rada vysokých škol), which also includes student representatives since 1993 and the Rectors' Conference. Notably, rectors, academics and students have repeatedly acted as a consolidated unit to protect university autonomy (Interview CZ-2). The heavy monopoly over policy-making is reflected in the high share of consultations going to a small number of formally recognized organizations, with the distinction from Poland that university workers are also more tightly involved in the corporatist arrangements. 


\section{Share of all reported consultations by organization per year - Slovenia}

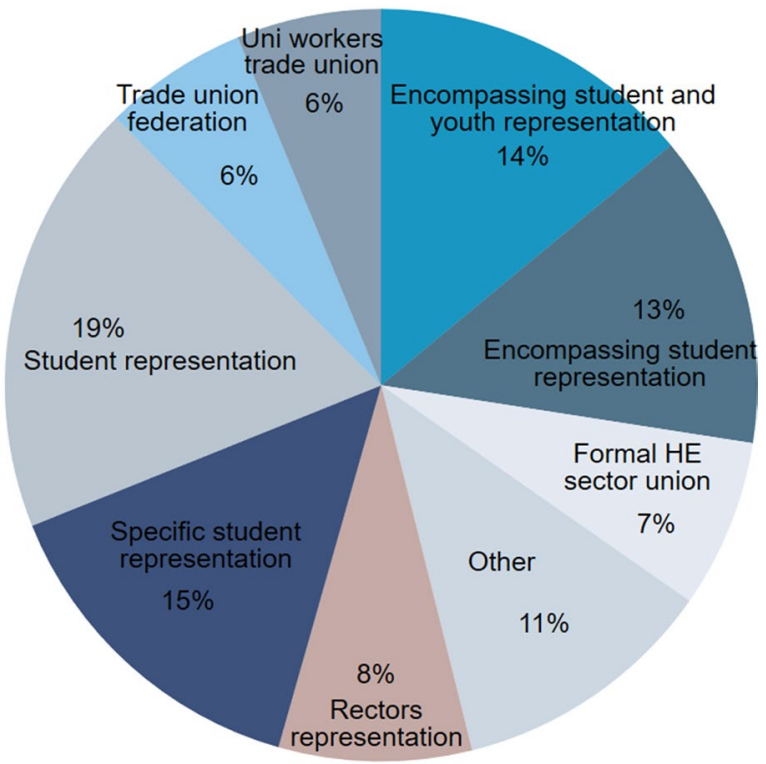

Source: own elaboration

Fig. 13 Share of consultations Slovenian organizations

No other external players such as employers, chambers of business or other public representatives have been intensively involved in Czech HE. Another striking feature is the active involvement of academic management in general politics, allowing for intensive inner and extra-parliamentary mobilization for academic interests. Former or even acting rectors and deans have been represented across different political parties, but consistently have been able to find a united position to defend their interests (Interview CZ-3). Thus, HE policy is generally coordinated directly by academic stakeholders with a "foot in the door" of the parliament to prevent overzealous state interventions into HE.

Slovenia is strikingly different. The university workers' movement-in line with broader corporatist traditions in Slovenian (Jahn 2016) - is more present in policymaking and represented by multiple organizations. Specifically, workers' organizations operate within the Economic and Social Council (ESC), which was established in 1994 and still functions as an important tripartite body for social partners and the government.

However, unlike in Poland and the Czech Republic no formalized platform for HE coordination exists, and again, in stark contrast to Poland, the rectors' conference emerged late (2005) as an informal organization ${ }^{12}$ and has not firmly established

${ }^{12}$ See http://www.rkrs.si/. 


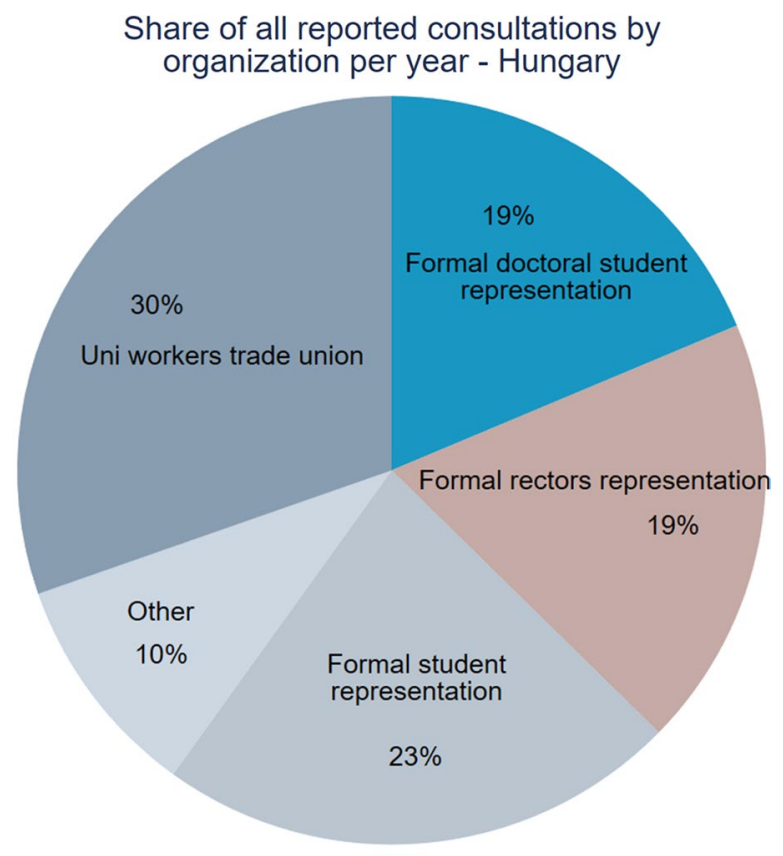

Source: own elaboration

Fig. 14 Share of consultations - Hungarian organizations

itself as the main addressee for university interests (see Fig. 13). Instead, individual Slovenian universities lobby the government and parliament individually. With only four universities, Slovenia also exhibits the greatest diversity of student interest groups, again reflected in Fig. 13, while none of them report having status as a formalized negotiation partner such as the Polish Parlament Studentów. We attribute the diversity of student activism to Slovenia's strong tradition of student democracy (Novak and Fink-Hafner 2019). Student groups have historically represented the multitude of political divisions and social movements in Slovenian society spanning from Catholicism, nationalism, communism, pan-Yugoslavianism, anarcholiberalism, to market socialism and beyond (Plut-Pregelj and Rogel 2007). Hence, we find (often long-standing) professional organizations for nearly every academic discipline and sub-discipline, as well as a strikingly large number of student organizations. Altogether, Slovenian HE appears corporatist when it comes to university workers' organizations being tightly involved in policy-making, albeit without one single encompassing organization, rather multiple workers' unions engaging with the state simultaneously. However, Slovenia is the most pluralist country regarding advocacy by students and the academic profession.

The Hungarian case reflects a continuous loss of academic freedom and increasingly weakening interest intermediation. The 1993 HE Act established interest intermediation forums, such as the HE Interest Intermediation Council or Accreditation Committee (MAB-Magyar Akkreditációs Bizottság) (Szövényi 2015, 8). In addition, the union confederation of academics'/researchers' unions along with other 
representative public sector union confederations was a member of the national-level tripartite interest intermediation council. Despite the steady decline of unionism and the gradual weakening of tripartism, HE interest groups were quite successful in defending attempts at curbing their financial autonomy and the implementation of tuition fees. However, HE autonomy shrank gradually already with an amendment in 1999, reducing the number of HE institutions significantly and giving the right of the appointments of professors to the MAB (Polónyi 2015). Since the adoption of the $2011 \mathrm{HE}$ Act there is a widening gap between the opportunities for access and interest intermediation of organizations enshrined in law (Rectors' Conference, HÖOK and DOSZ) ${ }^{13}$ and other HE interest groups. In our interviews with the DOSZ and the Rectors' Conference, the representatives of these organizations emphasized that they are consulted on every amendment and regulatory changes affecting HE (as stipulated by the $2011 \mathrm{HE}$ act). The DOSZ even successfully initiated a significant increase in the state-financed $\mathrm{PhD}$ positions (from 1300 to 2000 a year) in 2018. Yet the unions and particularly upstart, grassroots organizations are often left out from any consultations altogether.

However, access does not necessarily mean influence (Interview HU1; Interview HU3). The 2011 Act effectively emptied HE interest intermediation, while significantly constraining academic freedom. It changed the composition of the Hungarian HE Accreditation Committee so that the majority of its members are now government appointees and not appointees of the Rectors' Conference. The HE Interest Intermediation Council was degraded to a mere consultative body (Polónyi 2015). ${ }^{14}$

\section{Conclusions}

This analysis is, to our knowledge, the first comparative study of interest intermediation structures in post-communist HE. Our ambition was to outline the broader contours of policy-making and show how stakeholder regimes have evolved in the post-communist phase with a view to the Bologna Process, but also democratic backsliding tendencies. We relied on a combination of descriptive statistics, regression analysis as well as interviews and secondary literature to approach the topic from multiple angles.

While we do not have the means to compare our findings with interest intermediation structures in non-CEE countries, our data paint a general picture of highly consultative policy style, where many major stakeholder organizations enjoy easy access to major decision bodies. In other words, merely being a HE organization is a "ticket" to frequent political interactions compared to other policy groups. We also showed that stakeholder arrangements are only partially contingent on historical policy-making traditions or reflective of general forms of socio-economic corporatism (Jahn 2016). In a country otherwise not known for corporatist decision-making

\footnotetext{
13 Our scores for the Hungarian rectors' conference and DOSZ in Fig. 13 are based on interviews, not survey responses.

14 In the latest European University Association (EUA) report, Hungary scored low or medium-low in all four dimensions of academic freedom (organisational, financial, staffing, and academic).
} 
and characterized by pluralism and strong party interest group ties (Roberts 2009; Jahn 2016), Czech HE best reflects the corporatist paradigm, as HE matters are essentially governed by a small group of formally recognized stakeholders (students, rectors, university workers) within the Council of HE Institutions. These early postcommunist arrangements have remained remarkably stable. As for otherwise corporatist Slovenia (Jahn 2016), the strong inclusion of university workers, represented by multiple organizations, is indeed indicative of corporatism. Otherwise, however, Slovenia scores low on policy coordination and lacks a formal intermediation body for $\mathrm{HE}$, whereby university rectors only established a representative organization in the mid-2000s. Finally, the relative diversity of Slovenian student and academic organizations lacking a common voice speaks for a more pluralist interest group landscape, which in turn is reflective of the pluralistic organized academic and student interests under Yugoslav socialism.

The Polish interest intermediation system also enables the relatively equal participation of students and rectors, whereas - unlike in the Czech Republic - the academic profession and university workers are not equal consultation partners. Thus, our data point to a two-sided form of corporatism, in which one formally licensed student organization and a small number of non-licensed student organization shape policy along with the very influential Rectors' Conference.

In Hungary, the government successfully co-opted the Rectors' Conference and the main student organization during the 2012-2013 mass protests against a planned radical reduction in tuition-free places at public universities. In the new ad hoc consultative body, the HE Roundtable and the grassroots movements of the protest wave were excluded, although the president of the main HE union eventually was given a seat. Thus, during the last decade the most important HE interest organizations and union maintained access to policy-makers and regulatory authorities. However, their influence has been in fact very limited (Labanino and Dobbins 2020).

We see two major challenges for future research. While our data can generate insights on relationships between organized interests and political actors, they do not reveal whether tight corporatist arrangements go to the detriment of other potentially important actors, most notably external business stakeholders. Future research should therefore focus on how penetrable or secluded internal stakeholder structures are towards external stakeholders. Finally, scholars should rely on the case study method to examine to what extent different groups advocate opposite positions and explore their influence on concrete policies. Clearly, there is much to be done considering the low performance of these systems in HE rankings, a stronger focus on upgrading science and research in CEE amid persistent underfunding, and, above all, recent infringements on academic freedom in Hungary.

\section{Appendix (List of interview partners)}

Interview HU-1, Democratic Union of Teachers (PDSZ), 20 February 2019.

Interview HU-2, Labor Union of Higher Education Employees, 18 February 2019. 
Interview HU-3: Hungarian Rectors' Conference, 19 February 2019.

Interview HU-4: Students' Labor Union, 20 February 2019.

Interview HU-5: National Association of Doctoral Students (DOSZ), 18 February 2019.

Interview PL-1: Former rector of the University of Warsaw, 10 May 2019.

Interview PL-2: Dean of large faculty at UMCS Lublin, 9 May 2019.

Interview PL-3: Member of the executive committee of Parlament Studentów RP, 7 May 2019.

Interview CZ-1: Member of Council of Higher Education Institutions, 10 October 2019.

Interview CZ-2: Former rector of public university and deputy minister responsible for higher education and science, 12 December 2019.

Interview CZ-3: Former adviser to minister of education, 19 December 2019.

Funding Open Access funding enabled and organized by Projekt DEAL. This research was conducted as part of the research project "The Missing Link: Examining organized interests in post-communist policymaking" at the University of Konstanz, Germany and University of Opole, Poland funded by the Beethoven 2 Polish-German funding initiative of the Deutsche Forschungsgemeinschaft and the Narodowe Centrum Nauki. We sincerely thank both organizations for the generous funding.

\section{Declarations}

Conflict of interest On behalf of all authors, the corresponding author states that there is no conflict of interest.

Open Access This article is licensed under a Creative Commons Attribution 4.0 International License, which permits use, sharing, adaptation, distribution and reproduction in any medium or format, as long as you give appropriate credit to the original author(s) and the source, provide a link to the Creative Commons licence, and indicate if changes were made. The images or other third party material in this article are included in the article's Creative Commons licence, unless indicated otherwise in a credit line to the material. If material is not included in the article's Creative Commons licence and your intended use is not permitted by statutory regulation or exceeds the permitted use, you will need to obtain permission directly from the copyright holder. To view a copy of this licence, visit http://creativecommons.org/licen ses/by/4.0/.

\section{References}

Altbach, Philip G. 1997. Student politics in America: A historical analysis, Foundations of higher education. New Brunswick, NJ, USA: Transaction Publishers.

Čepič, Zdenko. 2018. The Student Movement 1968/1971 in Ljubljana in wider context. Contributions to Contemporary History 58 (3): 26-41.

della Porta, Donatella, and César. Guzmán-Concha. 2020. Contesting Higher Education: Student Movements Against Neo-Liberal Universities. Bristol: Bristol University Press.

Dobbins, Michael. 2011a. Explaining different pathways in higher education policy in Romania and the Czech Republic. Comparative Education 47 (2): 223-245. https://doi.org/10.1080/03050068.2011. 555116.

Dobbins, Michael. 2011b. Higher Education Policies in Central and Eastern Europe: Convergence towards a common model? Basingstoke: Palgrave Macmillan. 
Dobbins, Michael. 2014. French Education Politics after PISA and Bologna-Rupture or Continuité? In Internationalization of Education Policy: A New Constellation of Statehood in Education?, ed. Kerstin Martens, Philipp Knodel, and Michael Windzio, 115-141. London: Palgrave Macmillan UK.

Dobbins, Michael. 2017. Exploring higher education governance in Poland and Romania: Re-convergence after divergence? European Educational Research Journal 16 (5): 684-704. https://doi.org/ $10.1177 / 1474904116684138$.

Dobbins, Michael, Rafael Labanino, and Brigitte Horváthová. 2021. Exploring populations of organized interests in post-communist Central and Eastern Europe. In The "Missing Link": Exploring Organized Interests in Post-Communist Policy Making, ed. Michael Dobbins and Rafał Riedel, 47-76. Abingdon: Routledge.

EUA. 2017. University Autonomy in Europe III Country Profiles. In University Autonomy in Europe. Brussels: European University Association.

Greskovits, Béla. 2015. The Hollowing and Backsliding of Democracy in East Central Europe. Global Policy 6 (S1): 28-37. https://doi.org/10.1111/1758-5899.12225.

Guasti, Petra. 2016. Development of citizen participation in Central and Eastern Europe after the EU enlargement and economic crises. Communist and Post-Communist Studies 49 (3): 219-231. https:// doi.org/10.1016/j.postcomstud.2016.06.006.

Hansen, Lene. 1996. "Slovenian Identity: State-Building on the Balkan Border." Alternatives: Global, Local, Political 21 (4):473-495.

Howard, Marc Morjé. 2003. The weakness of civil society in post-Communist Europe. Cambridge, U.K. ; New York, NY: Cambridge University Press.

Jahn, Detlef. 2016. Changing of the guard: Trends in corporatist arrangements in 42 highly industrialized societies from 1960 to 2010. Socio-Economic Review 14 (1): 47-71. https://doi.org/10.1093/ ser/mwu028.

Junes, Tom. 2015. Student Politics in Communist Poland. Generations of Consent and Dissent. Lanham: Lexington Books.

Jungblut, Jens, and Regina Weber. 2012. National student governance in Germany: The case of fzs. European Journal of Higher Education 2 (1): 47-62. https://doi.org/10.1080/21568235.2012.683701.

Kavan, Jan. 2018. "Havel's Biafra of spirit? Prague Spring and the student movement." In the Long Run, 12.10. http://www.inthelongrun.org/articles/article/havels-biafra-of-spirit-prague-spring-and-thestudent-movement/.

Klemenčič, Manja. 2012. Student representation in Western Europe: Introduction to the special issue. European Journal of Higher Education 2 (1): 2-19. https://doi.org/10.1080/21568235.2012.695058.

Klemenčič, Manja. 2014. Student power in a global perspective and contemporary trends in student organising. Studies in Higher Education 39 (3): 396-411. https://doi.org/10.1080/03075079.2014. 896177.

Kopsa, Andy. 2019. Czechoslovakia's Velvet Revolution Started 30 Years Ago-But It Was Decades in the Making. Time 16 (11): 2019.

Kováts, Gergely. 2015. "Recent Developments in the Autonomy and Governance of Higher Education Institutions in Hungary: The Introduction of the Chancellor System." Central European Higher Education Cooperation Conference, Corvinus University, Budapest.

Kraus, Michael. 2007. Did the Charter 77 Movement Bring an End to Communism? New England Review (1990-) 28 (2): 134-146.

Kucsera, Tamás Gergely. 2010. Az országos fels óktatási hallgatói képviselet és a magyarországi hallgatói önkormányzati modell fejl ödéstörténete 1988-2008. PhD: Bölcsészettudományi Kar Interdiszciplináris Doktori Iskola, University of Pécs.

Labanino, Rafael, and Michael Dobbins. 2020. "'The goal is not necessarily to sit at the table'—Resisting autocratic legalism in Hungarian academia." Higher Education Quarterly n/a (n/a). https://doi.org/ 10.1111/hequ. 12290.

Labanino, Rafael, Michael Dobbins, and Rafał Riedel. 2021. There Is No Tabula Rasa - The effect of communist rule on organizational formations in pre-transition interest group populations. In The "Missing Link": Exploring Organized Interests in Post-Communist Policy Making, ed. Michael Dobbins and Rafał Riedel, 25-46. Abingdon: Routledge.

Luescher-Mamashela, Thierry M. 2013. Student representation in university decision making: Good reasons, a new lens? Studies in Higher Education 38 (10): 1442-1456. https://doi.org/10.1080/03075 079.2011 .625496 . 
McLendon, Michael K., James C. Hearn, and Christine G. Mokher. 2009. Partisans, Professionals, and Power: The Role of Political Factors in State Higher Education Funding. The Journal of Higher Education 80 (6): 686-713.

Murray, Elinor. 1960. Higher Education in Communist Hungary 1948-1956. American Slavic and East European Review 19 (3): 395-413. https://doi.org/10.2307/3001007.

Nantl, Ji.ř́. 2018. Academic Citizens: The case of Czech national student organization after the Velvet Revolution. International Review of Social Research 8 (1): 55-63. https://doi.org/10.2478/ irsr-2018-0007.

Novak, Meta, and Danica Fink-Hafner. 2019. Slovenia: Interest group developments in a postsocialistliberal democracy. Journal of Public Affairs 19 (2): 1-13.

OECD. 2006. OECD Thematic Review of Tertiary Education: Country Background Report for Poland. Warsaw: OECD.

Olson, Mancur. 1982. The rise and decline of nations : Economic growth, stagflation, and social rigidities. New Haven: Yale University Press.

Ost, David. 2011. 'Illusory Corporatism' Ten Years Later. Warsaw Forum of Economic Sociology 2 (3): 19-49.

Otáhal, Milan. 2003. Studenti a komunistická moc v českých zemích 1968-1989. Prague: Dokořán.

Pabian, Petr, Karel Šima, and Lucie Kynčilová. 2011. Humboldt goes to the labour market: How academic higher education fuels labour market success in the Czech Republic. Journal of Education and Work 24 (1-2): 95-118. https://doi.org/10.1080/13639080.2010.534443.

Plut-Pregelj, Leopoldina, and Carole Rogel. 2007. The A to Z of Slovenia. Plymouth: Scarecrow Press.

Polónyi, István. 2015. A hazai felsôoktatás-politika átalakulásai. Iskolakultúra 25 (5-6): 3-14. https://doi. org/10.17543/ISKKULT.2015.5-6.3.

Rainer, János. M. 2016. Nagy Imre. Budapest: Nagy Imre Alapítvány.

Ramšak, Jure. 2015. Radicalisation of the Criticism of "Real" Self-Management Socialism. Student Movement in Slovenia 1971-1974. Südost-Forschungen 74 (1): 111. https://doi.org/10.1515/ sofo-2015-0108.

Roberts, Andrew. 2009. The Politics of Healthcare Reform in Postcommunist Europe: The Importance of Access. Journal of Public Policy 29 (3): 305-325. https://doi.org/10.1017/S0143814X09990110.

Sata, Robert, and Ireneusz Pawel Karolewski. 2020. Caesarean politics in Hungary and Poland. East European Politics 36 (2): 206-225. https://doi.org/10.1080/21599165.2019.1703694.

Schmitter, Philippe C., and Wolfgang Streeck. 1999. The Organization of Business Interest. Studying Associative Action of Business in Advanced Industrial Societies. In MPIfG Discussion Paper. Cologne: Max-Planck-Institut für Gesellschaftsforschung.

Scott, Peter. 2002. Reflections on the Reform of Higher Education in Central and Eastern Europe. Higher Education in Europe 27 (1-2): 137-152. https://doi.org/10.1080/0379772022000003288.

Siaroff, Alan. 1999. Corporatism in 24 industrial democracies: Meaning and measurement. European Journal of Political Research 36 (2): 175-205. https://doi.org/10.1023/A:1007048820297.

Šustrová, Petruška. 2007. "Studenti v roce 1967: „Chceme světlo!“." Lidové noviny, 31.10.2007. https:// www.lidovky.cz/noviny/studenti-v-roce-1967-chceme-svetlo.A071031_000057_ln_noviny_sko.

Szövényi, Zsolt. 2015. Kormányzati ciklusok és felsőoktatás-politikai változások. In Közpolitikák és jogi környezetük, edited by Ákos Szalai. Budapest: Hungarian Academy of Sciences.

Ule, Mirjana, ed. 1998. Youth in Slovenia: New Perspectives from the Nineties. Ljubljana: Ministry of Education and Sport, Youth Department.

Ule, Mirjana. 2015. "Student activism in times of individualization: The case of Slovenia." In Student engagement in Europe: society, higher education and student governance, edited by Manja Klemenčič, Sjur Bergan and Rok Primožič, 67-82. Strasbourg: Council of Europe.

Ungváry, Krisztián. 2007. Egy eljárás genezise: A Dialógus Pécsett. Élet És Irodalom 18: 05.

van Beek, Ursula J. 1995. The Case of Poland. In Transformation mittel- und osteuropäischer Wissenschaftssysteme: Länderberichte, ed. Renate Mayntz, Uwe Schimank, and Peter Weingart, 256-301. Wiesbaden: VS Verlag für Sozialwissenschaften.

Vanhuysse, Pieter. 2007. Workers without Power: Agency, Legacies, and Labour Decline in East European Varieties of Capitalism. Sociologický Časopis / Czech Sociological Review 43 (3): 495-522.

Vlk, Aleš, Michael Dobbins, and Rafał Riedel. 2021. Explaining institutional persistence and change in Polish and Czech higher education from a stakeholder perspective. In The "Missing Link": Exploring Organized Interests in Post-Communist Policy-Making, ed. Michael Dobbins and Rafał Riedel, 173-193. Abingdon: Routledge. 
Vukasović, Martina. 2018. Stakeholder organizations and multi-level governance of higher education. In Handbook on the Politics of Higher Education, ed. Brendan Cantwell, Hamish Coates, and Roger King, 413-430. Cheltenham: Edward Elgar.

Weimer, Leasa. 2015. "Student union resistance to tuition fees in Finland." In Student Engagement in Europe: society, higher education and student governance, edited by Manja Klemenčič, Sjur Bergan and Rok Primožič, 113-125. Strasbourg: Council of Europe.

Woll, Cornelia. 2009. "The Demise of Statism?" In The French Fifth Republic at Fifty: Beyond Stereotypes, edited by Appleton, M. Andrew, Mazur, G. Amy, Brouard and Sylvain, 226-246. Palgrave Macmillan.

Zgaga, Pavel. 2002. Changes in Slovenian Higher Education: Governance, Autonomy, Admission, and Quality. Higher Education in Europe 27 (3): 325-332. https://doi.org/10.1080/037977202200001 5050 .

Publisher's Note Springer Nature remains neutral with regard to jurisdictional claims in published maps and institutional affiliations. 